UDC 94(470.45)“1971/1980”:378

Submitted: 04.12.2019

LBC 63.3(2Рос-4Вог)633-7

Accepted: 03.04.2020

\title{
PREHISTORY OF VOLGOGRAD STATE UNIVERSITY. 1971-1980
}

\author{
Sergey G. Sidorov \\ Volgograd State University, Volgograd, Russian Federation \\ Vasily V. Tarakanov \\ Volgograd State University, Volgograd, Russian Federation; \\ "Institute of Economic and Social Research" Foundation, Volgograd, Russian Federation
}

\begin{abstract}
Introduction. The authors analyze the process of establishing a state university in Volgograd, the last university set up in the RSFSR during the existence of the USSR. Materials. This study is based on the basis of archival materials first introduced into scientific use (State Archive of the Russian Federation (SARF), Russian State Archive of Recent History (RSARH), Center of Recent History Documentation of Volgograd Region (CRHDVO)). Analysis and Results. The initial idea of the representatives of governing bodies in Volgograd region to organize a university on the basis of Volgograd Polytechnic Institute did not find support from the leadership of the country in 1971. In 1972 it was decided to start organizing a new type of higher education institution for Volgograd, that is a classic university. This idea found support in Moscow, which was manifested in the resolutions of the Secretariat of the CPSU Central Committee in 1973 and the USSR Council of Ministers and the RSFSR Council of Ministers in 1974. The necessity for creating appropriate educational and teaching resources and facilities, the manpower problem and insufficient funds led to postponing initially proposed dates for the University opening from 1974 to 1978, and then to 1980. The first admission of students in 1980 was in the building of a comprehensive school specially built for this purpose near the future University complex, the first building of which would be put into service only in 1983. The issue of the development of the young University was under the constant control of the Council of Ministers of the RSFSR for many years. Only in March 1986 it was decided to discontinue supervision over the resolution of the Council of Ministers of the RSFSR no. 561 of October 21, 1974.

Key words: Volgograd State University, USSR Council of Ministers, RSFSR Council of Ministers, RSFSR Ministry of Higher Education Institutions, Volgograd Regional Committee of CPSU.

Citation. Sidorov S.G., Tarakanov V.V. Prehistory of Volgograd State University. 1971-1980. Vestnik Volgogradskogo gosudarstvennogo universiteta. Seriya 4. Istoriya. Regionovedenie. Mezhdunarodnye otnosheniya [Science Journal of Volgograd State University. History. Area Studies. International Relations], 2020, vol. 25, no. 2, pp. 128-146. (in Russian). DOI: https://doi.org/10.15688/jvolsu4.2020.2.9
\end{abstract}

УДК 94(470.45)“1971/1980”:378

Дата поступления статьи: 04.12.2019

ББК 63.3(2Рос-4Вог)633-7

Дата принятия статьи: 03.04.2020

ПРЕДЫСТОРИЯ ВОЛГОГРАДСКОГО ГОСУДАРСТВЕННОГО УНИВЕРСИТЕТА. 1971-1980 ГОДЫ

\section{Сергей Григорьевич Сидоров}

Волгоградский государственный университет, г. Волгоград, Российская Федерация

\section{Василий Валерьевич Тараканов}

Волгоградский государственный университет, г. Волгоград, Российская Федерация; Фонд «Институт экономических и социальных исследований», г. Волгоград, Российская Федерация

Аннотация. В статье на основе архивных материалов (ГАРФ, РГАНИ, ЦДНИВО), впервые вводимых в научный оборот, анализируется процесс создания государственного университета в городе Волгограде, пос- 
леднего университета, открытого в РСФСР в период существования СССР. Первоначальная идея руководства Волгоградской области организовать в 1971 г. университет на базе Волгоградского политехнического института не нашла поддержки у руководства страны. В 1972 г. приступили к организации нового для Волгограда вида высшего учебного заведения - классического университета. Это нашло поддержку в Москве, что выразилось в постановлениях Секретариата ЦК КПСС 1973 г. и Совмина СССР и Совмина РСФСР 1974 года. Необходимость создания соответствующей учебно-материальной базы, недостаток сил и средств привели к переносу предлагаемых первоначально сроков открытия университета с 1974 г. на 1978 г., а затем и на 1980 год. Первый набор студентов в 1980 г. был произведен в здании общеобразовательной школы, специально построенном для этого недалеко от будущего университетского комплекса, первый корпус которого будет сдан только в 1983 году. Вопрос о развитии молодого университета долгие годы находился на постоянном контроле Совета Министров РСФСР. Только в марте 1986 г. было принято решение о целесообразности снятия с контроля Постановления Совмина РСФСР № 561 от 21 октября 1974 года.

Ключевые слова: Волгоградский государственный университет, Совмин СССР, Совмин РСФСР, Минвуз РСФСР, Волгоградский обком КПСС.

Цитирование. Сидоров С. Г., Тараканов В. В. Предыстория Волгоградского государственного университета. 1971-1980 годы // Вестник Волгоградского государственного университета. Серия 4, История. Регионоведение. Международные отношения. - 2020. - Т. 25, № 2. - С. 128-146. - DOI: https://doi.org/10.15688/jvolsu4.2020.2.9

Введение. В 1980 г. Волгоградский государственный университет (ВолГУ) осуществил первый набор студентов на дневное отделение по пяти специальностям. Этому знаменательному для Волгограда и области моменту предшествовала многолетняя работа руководства региона по воплощению мечты в жизнь. От первой попытки создания государственного университета в 1971 г. до его официального открытия прошло девять лет, в течение которых предполагаемый год первого приема студентов переносился несколько раз.

Материалы. С момента открытия Волгоградского государственного университета прошло почти сорок лет. За этот небольшой для вуза срок преподаватели и сотрудники ВолГУ подготовили десятки тысяч высококвалифицированных специалистов.

История становления и развития университета нашла отражение в научной литературе. Одними из первых публикаций стали статистические справочники, подготовленные проректором по учебной работе С.Г. Сидоровым к 15-летию [43] и 20-летию вуза [41]. В 2004 г. вышел в свет специальный выпуск «Вестника Волгоградского государственного университета», посвященный 80-летию первого ректора М.М. Загорулько [1]. В 2005 г. издана монография С.Г. Сидорова, раскрывающая 25-летнюю историю развития ВолГУ [42]. К 30-летию университета опубликованы воспоминания преподавателей и сотрудников, студентов и аспирантов вуза [2]. В 2016 г. вышел второй сборник воспоминаний [4]. Однако все названные и дру- гие публикации не затрагивают предыстории университета, не раскрывают процесса воплощения в жизнь идеи создания в Волгограде классического университета.

В основу статьи положены источники, впервые вводимые в научный оборот. Среди них документы: Совета Министров СССР (Совмина СССР) - Ф. 5446, Совета Министров РСФСР (Совмина РСФСР) - Ф. А-259 и Министерства высшего и среднего специального образования СССР (Минвуза СССР)Ф. 9606, находящиеся в Государственном архиве Российской Федерации (ГАРФ); Волгоградского обкома КПСС - Ф. 113, Волгоградского горкома КПСС - Ф. 71, хранящиеся в Центре документации новейшей истории Волгоградской области (ЦДНИВО). Директором Российского государственного архива новейшей истории (РГАНИ) предоставлена копия Постановления Секретариата ЦК КПСС № СТ-93/6c от 21.08.1973 г. «Об организации Государственного университета в г. Волгограде».

Анализ. В начале 1970-х гг. в СССР имелось 63 университета, в том числе 38 в РСФСР. Около трети из них (18) были организованы в 1967-1973 гг. [23], девять из которых на территории РСФСР. Создание университетов в эти годы шло двумя путями: на базе педагогических институтов и как вновь образуемые высшие учебные заведения. В РСФСР в указанные годы по первому пути были созданы Калмыцкий (1970), Краснодарский (1970), Тверской (1971), Удмуртский (1971) и Ивановский (1973), по второму пути - Чувашский (1967), 
Ярославский (1970), Марийский (1972) и Алтайский (1973) государственные университеты.

В соседних с Волгоградом областных центрах - Ростове-на-Дону, Воронеже, Саратове университеты работали уже долгие годы, готовя кадры и для Волгоградской области. Однако этого было явно недостаточно. По ориентировочным подсчетам только в научно-исследовательских учреждениях Волгоградской области к середине 1970-х гг. потребность в кадрах с университетским образованием могла составить 1500 человек, в первую очередь математиков, физиков, биологов, химиков и представителей других специальностей [12].

Необходимость открытия в Волгограде университета давно назрела. Волгоградская область являлась крупным промышленным и сельскохозяйственным центром Нижнего Поволжья. В области успешно развивались предприятия черной и цветной металлургии, химической, нефтехимической, микробиологической и машиностроительной отраслей промышленности. Значительно возрос объем орошаемого земледелия, создавались высокомеханизированные комплексы по производству продуктов животноводства на промышленной основе.

Область являлась крупным культурным и научным центром, имела шесть высших учебных заведений - отраслевых институтов (политехнический, медицинский, педагогический, сельскохозяйственный, физического воспитания, инженеров городского хозяйства). В вузах и научных учреждениях г. Волгограда работало 119 докторов и 1140 кандидатов наук. В области находилось 37 средних специальных учебных заведений, 62 профессионально-технических училища, свыше двух тысяч общеобразовательных школ, в том числе около пятисот средних.

Оснащение предприятий новейшим оборудованием, электронно-вычислительными машинами, разработка научно-технических проблем, повышение эффективности производства на базе достижений технического прогресса вызывали необходимость организации подготовки кадров с университетским образованием, особенно специалистов по обслуживанию вычислительной техники, математиков, физиков, экономистов, биологов и химиков $[18$, л. $27-28 ; 20$, л. $1-2 ; 25$, л. 11-12].
В 1970 г. на базе педагогического института был создан Калмыцкий государственный университет. Это, несомненно, подтолкнуло руководство Волгоградской области к необходимости предпринять меры по открытию в области своего университета. Изучив имеющийся в стране опыт и местную специфику, руководство области попыталось пойти своим путем. Если до этого в стране, как правило, университеты создавали как вновь образуемые высшие учебные заведения или на базе педагогических институтов, то в области решили организовать университет на базе политехнического института. К началу 1971 г. в институте работало 12 докторов и 182 кандидата наук, обучалось 5200 студентов по очной форме обучения по 16 специальностям. 21 июля 1971 г. первый секретарь Волгоградского обкома КПСС Л.С. Куличенко направил в ЦК КПСС письмо «О преобразовании Волгоградского политехнического института в Государственный университет» [9].

Обосновывая необходимость создания «университета нового типа, призванного вести комплексные научные исследования и обеспечить подготовку научных, научно-педагогических и инженерных кадров», Л.С. Куличенко предлагал в качестве эксперимента открыть на базе политехнического института 14 новых, главным образом университетских специальностей. В их числе значились философия, политическая экономия, химия, физика, прикладная математика, механика и др. Сочетание университетских и технических специальностей, по мнению руководства области, должно было «способствовать подъему прикладной науки до уровня фундаментальных наук, росту эффективности вузовских научных исследований, повышению качества подготовки выпускаемых специалистов». В последнем абзаце письма звучала уверенность, что «создание Волгоградского государственного университета должно плодотворно сказаться на решении проблемы подготовки и повышения квалификации научных, научнопедагогических и инженерных кадров для большого числа высших и средних специальных учебных заведений, научно-исследовательских и проектных институтов, промышленных, строительных и транспортных предприятий городов и сел Волгоградской, Астра- 
ханской, Гурьевской, Оренбургской областей, а также других районов нашей страны».

Предложение первого секретаря Волгоградского обкома КПСС о создании университета на базе политехнического института не нашло поддержки в Москве. После этого предпринимается вторая попытка получить разрешение на открытие университета. Руководство области отказалось от прежней идеи. Решили открывать университет не на базе какого-либо существующего в Волгограде вуза, а как вновь создаваемое высшее учебное заведение.

21 августа 1973 г. вопрос «Об организации государственного университета в г. Волгограде» был рассмотрен на заседании Секретариата ЦК КПСС. Все 5 секретарей ЦК КПСС (А.П. Кириленко, П.Н. Демичев, В.И. Долгих, К.Ф. Катушев и Ф.Д. Кулаков) проголосовали за положительное решение вопроса. В подготовленный к заседанию проект постановления было внесено небольшое уточнение. В начале первого пункта слова «принять предложение» заменены на «положительно отнестись к предложению». В целом постановление Секретариата состояло из двух пунктов:

«1. Положительно отнестись к предложению Волгоградского обкома КПСС об организации в г. Волгограде Государственного университета.

2. Поручить Совету Министров РСФСР и Министерству высшего и среднего специального образования СССР совместно с Волгоградским обкомом КПСС внести соответствующие предложения в Совет Министров СССР».

24 августа выписка из решения была разослана председателю Совета Министров РСФСР М.С. Соломенцеву, министру высшего и среднего специального образования СССР В.П. Елютину, управляющему делами Совета Министров СССР М.С. Смиртюкову, заведующему отделом науки и учебных заведений ЦК КПСС С.П. Трапезникову и в Волгоградский обком КПСС [15].

Таким образом, принципиальное согласие на открытие университета в г. Волгограде со стороны высшего партийного руководства было получено. С этого времени началось решение организационных вопросов в партийных органах и органах исполнительной власти СССР и РСФСР.
24 сентября 1973 г. постановление ЦК КПСС от 21 августа было рассмотрено на заседании бюро областного комитета КПСС и принято к руководству и исполнению [36]. Специально созданной комиссии в составе Н.Р. Прокофьевой, А.В. Дынкина, И.М. Королева, М.М. Загорулько под председательством В.Ф. Шилина было поручено в месячный срок внести на бюро обкома КПСС конкретные предложения, связанные с созданием университета в Волгограде. Соответствующие предложения были подготовлены и отправлены в Москву.

В октябре 1973 г. на подпись председателю Совмина РСФСР М.С. Соломенцеву и министру высшего и среднего специального образования СССР В.П. Елютину был представлен проект письма в Совет Министров СССР. В нем содержалась характеристика экономического состояния Волгоградской области и обосновывалась необходимость открытия университета. Текст письма завершался словами: «Совет Министров РСФСР и Министерство высшего и среднего специального образования СССР просят организовать в 1974 г. в г. Волгограде Волгоградский государственный университет, разрешив Совету Министров РСФСР проектирование в 1974-1975 гг. учебно-лабораторных зданий университета общей площадью 20 тысяч квадратных метров» [18].

К письму прилагался проект постановления Совмина СССР «Об организации в г. Волгограде Государственного университета», в котором говорилось:

«Совет Министров Союза ССР постановляет:

1. Принять предложение Совета Министров РСФСР и Министерства высшего и среднего специального образования СССР об организации в 1974 г. в г. Волгограде Волгоградского государственного университета Министерства высшего и среднего специального образования РСФСР.

2. Обязать Совет Министров РСФСР обеспечить проектирование и строительство в 1974-1978 гг. учебно-лабораторных зданий Волгоградского университета общей площадью 20 тыс. кв. метров» [16].

Сопроводительное письмо и проект постановления Совмина СССР 2 ноября был 
согласован с заинтересованными лицами, в том числе с руководством Волгоградской области. 5 ноября секретарь обкома КПСС Л.С. Куличенко и председатель исполкома облсовета Ю.И. Ломакин направили в Совет Министров РСФСР на имя М.С. Соломенцева письмо с перечнем мер, обеспечивающих открытие Волгоградского университета в 1974 году. Руководство области брало на себя обязательство передать будущему университету комплекс зданий школы-интерната № 1 общей площадью 6611 кв. м и за счет средств местных Советов в 1974 г. построить учебнолабораторный корпус площадью 6000 кв. метров. Для создания необходимых жилищнобытовых условий студентам университета, профессорско-преподавательскому составу за счет средств облисполкома в 1974-1975 гг. намечалось построить и ввести в эксплуатацию общежитие для студентов на 1054 места, дом для профессорско-преподавательского состава на 100 квартир и студенческую столовую на 350 мест. Под строительство объектов университета исполком горсовета выделил земельный участок площадью 40 гектаров.

В целях обеспечения нормальной работы университета в последующие годы обком КПСС и исполком облсовета просили Совет Министров РСФСР предусмотреть проектирование в 1974-1975 гг. и строительство в 1976-1978 гг. учебно-лабораторных зданий университета общей площадью 20 тыс. кв. м и выделение для этого целевым назначением необходимых капитальных вложений Министерству высшего и среднего специального образования РСФСР [17].

11 ноября Председатель Совмина РСФСР М.С. Соломенцев поручил председателю Госплана РСФСР К.М. Герасимову и министру высшего и среднего специального образования РСФСР И.Ф. Образцову рассмотреть просьбу Волгоградского обкома КПСС и облисполкома от 5 ноября 1973 года [40].

27 ноября председатель Госплана РСФСР К.М. Герасимов поддержал предложение Минвуза РСФСР и выразил готовность в установленном порядке оформить титульный список на проектирование указанных зданий послепринятия Советом Министров СССР положительного решения по этому вопросу.
Для этого Госплан РСФСР зарезервировал лимит проектных работ на 1974 г. в объеме 50 тыс. рублей, о чем проинформировал Совет Министров РСФСР [10].

К этому времени в Совете Министров РСФСР был согласован второй вариант проекта постановления Совета Министров СССР. От первого варианта он отличался лишь незначительно:

«Совет Министров Союза ССР постановляет:

Принять предложение Совета Министров РСФСР и Министерства высшего и среднего специального образования СССР:

- об организации в 1974 г. в г. Волгограде Волгоградского государственного университета Министерства высшего и среднего специального образования РСФСР;

- о проектировании и строительстве в 1974-1978 гг. учебно-лабораторных зданий Волгоградского университета общей площадью 20 тыс. кв. метров» [19].

Однако и этот проект постановления не устроил Совмин СССР. 21 января 1974 г. после дополнительной проработки вопроса председатель Совмина РСФСР М.С. Соломенцев и министр высшего и среднего специального образования СССР В.П. Елютин внесли в Совет Министров СССР очередной проект постановления об организации госуниверситета в г. Волгограде с соответствующим сопроводительным письмом [20].

23 января вопрос «О мерах по подготовке к открытию Волгоградского государственного университета» изучил исполком Волгоградского облсовета депутатов трудящихся и принял решение «просить Совет Министров РСФСР рассмотреть вопрос о проектировании и строительстве в 1979-1980 гг. комплекса Волгоградского государственного университета на 3,5 тыс. студентов дневного отделения» и «разрешить исполкому облсовета за счет капиталовложений по соответствующей отрасли построить для Волгоградского государственного университета в 1974-1976 гг. школу на 1320 мест, общежитие для студентов на 1000 мест, жилой дом на 100 квартир для профессорско-преподавательского состава и студенческую столовую на 350 мест» [7].

28 января заместитель председателя Совета Министров Н.А. Тихонов поручил за- 
местителю председателя Госплана СССР М.Е. Раковскому, министру финансов СССР В.Ф. Гарбузову и министру просвещения СССР М.А. Прокофьеву дать заключение на предложение Совмина РСФСР и Минвуза СССР об организации Волгоградского государственного университета [35].

После изучения вопроса 15 февраля M.Е. Раковский направил в Совет Министров СССР письмо, в котором сообщал, что «Госплан СССР не возражает против организации Волгоградского государственного университета Министерства высшего и среднего специального образования РСФСР» [21].

Министерство финансов СССР положительное заключение в адрес Совета Министров СССР за подписью заместителя министра финансов СССР В.В. Деменцева направило 26 февраля. Не последнюю роль в поддержке предложения Совмина РСФСР и Минвуза СССР сыграли обязательства Волгоградского облисполкома передать под университет комплекс зданий школы-интерната № 8, a также построить учебно-лабораторный корпус, общежитие, студенческую столовую и жилой дом на 100 квартир для профессорскопреподавательского состава [22].

Заключение Минпроса СССР не было однозначным. Министр просвещения СССР М.А. Прокофьев в целом не возражал против организации Волгоградского университета, но он выступил категорически против закрытия школы-интерната № 8 г. Волгограда и передачи ее учебно-материальной базы под университет. В письме в Совет Министров СССР от 26 февраля М.А. Прокофьев так мотивировал свой отказ: «В настоящее время в Волгоградской области сложилось неблагоприятное положение с устройством и воспитанием детей, нуждающихся в государственной помощи. В 1973 г. возросло число правонарушений несовершеннолетних по сравнению с 1972 г. на 6,8 \%. В последние годы в области закрыты три школы-интерната, вследствие чего контингент воспитанников сократился с 9060 до 6500 чел. (на $28 \%$ ).

По сообщению Министерства просвещения РСФСР в школе-интернате № 8 содержится 380 воспитанников, в том числе 85 детей, лишившихся попечения родителей, 45 детей инвалидов труда и одиноких матерей, 250 че- ловек из многодетных семей. Около 40 \% воспитанников поступают в школу из сельской местности. В области не хватает помещений и для общеобразовательных школ. В текущем году из 140 общеобразовательных школ 111 работают в две смены, а четыре - в три смены. В Октябрьском ${ }^{1}$ районе города, где размещается школа-интернат № 8,35 \% учащихся обучаются во вторую смену. Две школы находятся в аварийном состоянии.

В крайне тяжелых условиях работают и детские дома области. В связи с этим возникает необходимость перевода воспитанников в школы-интернаты» [28].

Управление делами Совмина СССР изучило предложение Совета Министров РСФСР и Минвуза СССР, заключения Госплана СССР, Минфина СССР и Минпроса СССР и подготовило для первого заместителя Председателя Совета Министров СССР К.Т. Мазурова краткую справку. Изложив доводы сторон, управление делами сделало вывод: «Вызывает сомнение в реальности организации университета (так в тексте. - C. C., В. T.) в 1974 г., так как университет фактически не будет обеспечен учебно-материальной базой, позволяющей организовать занятия со студентами с 1 сентября 1974 года». Кроме того, в справке сообщалось, что заместитель министра высшего и среднего специального образования РСФСР В.П. Усачев выезжал по этому вопросу в г. Волгоград и предлагал в обкоме КПСС повременить с организацией университета до создания минимальной учебно-материальной базы. Однако секретарь обкома КПСС Л.С. Куличенко настаивал на организации университета в 1974 году. В последнем абзаце справки содержалось напоминание, «что в решении Секретариата ЦК КПСС не установлен конкретный срок организации университета» [45].

К.Т. Мазуров ознакомился с материалами по делу открытия университета в г. Волгограде 1 марта, после чего на письме с предложением Совмина РСФСР и Минвуза СССР появилась его резолюция: «Рассмотреть на Президиуме Совмина» [39].

К заседанию Президиума Управление делами Совета Министров СССР подготовило более подробную справку, в которой в основном рассматривались замечания по про- 
екту. Внимание членов Президиума заострялось на категорическом возражении министра просвещения СССР М.А. Прокофьева против закрытия школы-интерната № 8 в г. Волгограде и передачи ее учебно-материальной базы под университет. В связи с этим открытию университета и организации занятий со студентами с 1 сентября 1974 г. мешало отсутствие учебно-материальной базы. Также нереальным было обеспечение облисполкомом строительства в 1974 г. учебно-лабораторного корпуса площадью 6 тыс. кв. м, так как, по данным Минвуза РСФСР, еще не была разработана проектно-сметная документация. В то же время капитальных вложений Минвуза РСФСР не хватало даже для завершения строительства начатых и уже проектируемых объектов [23].

Рассмотрение вопроса в правительстве СССР застопорилось. 23 мая 1974 г. старший референт Управления делами Совмина СССР Г. Морозов подготовил на имя К.Т. Мазурова очередную справку к вопросу организации Волгоградского государственного университета. Копия справки одновременно была направлена в Минвуз СССР [24]. Содержание данной справки практически ничем не отличалось от мартовского варианта. Г. Морозов лишь в последнем абзаце напомнил, что «Совмин СССР 1 марта 1974 г. принял решение рассмотреть указанное ходатайство на Президиуме Совмина».

Первый заместитель Председателя Совета Министров СССР, ознакомившись с содержанием справки, в верхнем углу на первом листе написал: «Тов. Елютину В.П. Прошу рассмотреть вопрос о создании в Волгограде университета в перспективе, подготовьте проект решения Совмина, согласовав предварительно с секретарем обкома тов. Куличенко. 24 мая 1974 г. К.Т. Мазуров» [24].

Выполняя данное указание, В.П. Елютин поручил начальнику учебно-методического управления проф. А.И. Богомолову и начальнику планово-финансового управления Д.И. Чупрунову Минвуза СССР подготовить необходимые проекты документов.

Дополнительно рассмотрев предложения Волгоградского обкома КПСС и облисполкома об организации университета в г. Волгограде, А.И. Богомолов 17 июня подготовил новый проект постановления Совета Министров СССР :
«Совет Министров постановляет:

1. Обязать Совет Министров РСФСР построить в 1974-1978 гг. в г. Волгограде комплекс учебных зданий, общежитий и жилых домов для Волгоградского государственного университета.

По окончании строительства указанных зданий передать их на баланс Министерства высшего и среднего специального образования РСФСР.

2. Министерству высшего и среднего специального образования СССР по мере завершения строительства организовать в 19771978 гг. в г. Волгограде Волгоградский государственный университет» $[25 ; 26]$.

Проект, завизированный В.П. Елютиным, был согласован с Советом Министров РСФСР. В делах Совмина РСФСР сохранилась соответствующая справка от 19 июня за подписью заведующего отделом высшего, среднего и профессионально-технического образования Управления Делами Совета Министров РСФСР Н.А. Андрианова [33].

19 июня вопрос об организации Волгоградского государственного университета был наконец-то рассмотрен на заседании Президиума Совета Министров СССР. Предложение Совета Министров РСФСР и Минвуза СССР было принято [27].

21 июня 1974 г. за № 510 вышло постановление Совета Министров СССР. В отличие от проекта, в нем уже не было конкретных сроков:

«Совет Министров СССР постановляет:

Принять предложение Совета Министров РСФСР и Министерства высшего и среднего специального образования СССР об организации в г. Волгограде Государственного университета Министерства высшего и среднего специального образования РСФСР.

Поручить Совету Министров РСФСР, Госплану СССР и Министерства высшего и среднего специального образования СССР рассмотреть и решить вопросы, связанные с созданием необходимой учебно-материальной базы для обеспечения нормальной работы указанного университета, и определить срок его открытия.

Зам. председателя Совета Министров СССР К. Мазуров

Управляющий Делами Совета Министров СССР М. Смиртюков» [29]. 
С выходом постановления Совмина СССР начинается новый этап в подготовке открытия университета в г. Волгограде. 26 июня заместитель председателя Совмина РСФСР В.И. Кочемасов поручил Н.С. Зенченко (Госплан РСФСР), И.Ф. Образцову (Минвуз РСФСР) и Ю.И. Ломакину (Волгоградский облисполком) в трехмесячный срок подготовить и представить согласованные с Госпланом СССР и Минвузом СССР предложения о создании учебно-материальной базы университета в г. Волгограде и о сроках его открытия [11].

12 сентября председатель исполкома Волгоградского областного совета депутатов трудящихся Ю.И. Ломакин направил в Совмин РСФСР соответствующие предложения. Исполком облсовета считал целесообразным иметь в будущем Волгоградском университете физический, механико-математический, химический, биолого-почвенный, экономический, философский, филологический (русский и романо-германский языки и литература) факультеты с общим количеством студентов 10-12 тыс. человек. Открыть университет, считал Ю.И. Ломакин, возможно в 1978 году. Для этого он предлагал поручить Минвузу РСФСР разработать и утвердить в установленном порядке плановое задание на развитие университета, изготовить в 1975-1976 гг. технический проект всего комплекса университета и рабочие чертежи первой очереди. Председатель исполкома Волгоградского областного совета депутатов трудящихся полагал, что часть проектных работ совместно с Гипровузом может выполнить проектный институт «Волгоградгражданпроект». Начать строительство предлагалось в 1976 г. и завершить его первую очередь в 1978 г., для чего организовать с 1 апреля 1975 г. дирекцию строительства университета. «Территорию для университета, - писал Ю.И. Ломакин, - исполком Волгоградского горсовета выделил в лесопарковом поясе в соответствии с действующими нормами» [12].

17 сентября В.И Кочемасов переадресовал письмо Ю.И. Ломакина заместителю председателя Госплана РСФСР И.М. Груздеву и министру высшего и среднего специального образования РСФСР И.Ф. Образцову [34].
Госплан РСФСР и Минвуз РСФСР также рассмотрели указанный вопрос. Выработанные предложения они согласовали с Госпланом СССР (М.Е. Раковским) и Минвузом СССР (Н.С. Егоровым). Это было необходимо, так как по существовавшему положению технико-экономическое обоснование на строительство и проектирование объектов высших учебных заведений стоимостью строительства более 10 млн руб. должно было утверждаться Советом Министров РСФСР по согласованию с этими органами.

26 сентября согласованные предложения И.М. Груздев и И.Ф. Образцов направили в Совмин РСФСР. Они считали «целесообразным предусмотреть в проекте плана изыскательских и проектных работ на 1975 г. разработку технико-экономического обоснования на весь комплекс университета с выделением первой очереди строительства. Проектный институт “Гипровуз” Минвуза СССР согласен выполнить эту работу в 1975 г. и осуществить дальнейшее проектирование комплекса зданий университета в г. Волгограде». Открытие же университета откладывалось на более поздний срок, чем предлагал Ю.И. Ломакин. К 1978 г. предлагалось осуществить проектирование первой очереди университета и начать его строительство. «Что касается сроков открытия университета, то Госплан РСФСР и Минвуз РСФСР считают целесообразным открыть университет после завершения строительства первой очереди» [13].

В соответствии с поступившими предложениями был подготовлен проект постановления Совмина РСФСР, который к 15 октября прошел согласование с Госпланом СССР, Минвузом СССР, Госпланом РСФСР, Минвузом РСФСР и Волгоградским облисполкомом [47]. В связи с госпитализацией Ю.И. Ломакина проект постановления 15 октября был согласован с его первым заместителем Б.Г. Широковым. Однако уже на следующий день Б.Г. Широков сообщил в Совет Министров РСФСР, что Ю.И. Ломакин настаивает на окончании строительства первой очереди университета в 1978 году.

В связи с этим 17 октября заведующий отделом высшего, среднего и профессионально-технического образования Совмина РСФСР Н. Андрианов подготовил справку о 
нереальности окончания строительства университета в г. Волгограде в 1978 году. С доводами начальника отдела В.И. Кочемасов согласился [48].

21 октября Совет Министров РСФСР принял постановление № 561 «Об организации в г. Волгограде Государственного университета»:

«В соответствии с постановлением Совета Министров СССР от 21 июня 1974 г. № 510 Совет Министров РСФСР постановляет:

Обязать Министерство высшего и среднего специального образования РСФСР обеспечить:

- разработку в 1975 г. технико-экономического обоснования строительства комплекса зданий и сооружений Государственного университета в г. Волгограде;

- совместно с Волгоградским облисполкомом проектирование и строительство в 1976-1980 гг. зданий и сооружений университета первой очереди в составе учебно-лабораторных корпусов полезной площадью 16 тыс. кв. метров, столовой на 530 посадочных мест и студенческих общежитий на 1100 мест;

- организацию Государственного университета в г. Волгограде в 1980 г. и укомплектование его преподавательскими кадрами, имеющими ученые степени и звания.

Зам. председателя Совета Министров РСФСР Н. Васильев

Управляющий делами Совета Министров РСФСР И. Смирнов» [30].

В соответствии с постановлением Минвуз РСФСР 30 октября 1974 г. издал приказ № 469 об организации в г. Волгограде государственного университета и включил в план Гипровуза на 1975 г. разработку технико-экономического обоснования, которое было утверждено распоряжением Совета Министров РСФСР только 18 июля 1977 года.

Технико-экономическое обоснование предусматривало проектирование и строительство комплекса зданий университета в период 1976-2000 гг. в составе 5 факультетов, подготовительного отделения, аспирантуры и ФПК. Общая сметная стоимость строительства комплекса зданий университета была определена в сумме 71,5 млн рублей.

В 1978 г. Гипровуз разработал технический проект на строительство первой очереди комплекса зданий и сооружений университета, который Совет Министров РСФСР утвердил распоряжением от 16 февраля 1979 года.

Общая площадь учебно-лабораторного и спортивного корпусов составляла 17,78 тыс. кв. м, столовой - 530 посадочных мест. Сметная стоимость строительства первой очереди составляла 8,1 млн рублей.

В 1979 г. были разработаны рабочие чертежи на первый год строительства сметной стоимостью на 1,5 млн руб. строительно-монтажных работ.

В целях своевременной инженерной подготовки площадки под строительство объектов первой очереди с Волгоградским горисполкомом было согласовано строительство отопительной котельной, инженерных коммуникаций и сооружений. На эти цели Министерство передало городским организациям на 1978-1979 гг. 1,3 млн рублей.

В 1978 г. Министерство приступило к строительству студенческого общежития для университета на 1085 мест. Для обеспечения ввода его в эксплуатацию совместно с народнохозяйственным планом Волгоградскому облисполкому на 1979 г. передали капитальные вложения в сумме 950 тыс. рублей. Ввод общежития в эксплуатацию планировался на второй квартал 1980 года [49].

В связи с задержкой начала строительства учебно-лабораторного корпуса по просьбе Минвуза РСФСР Волгоградский облисполком осуществил строительство типовой общеобразовательной школы на 1176 мест общей полезной площадью 6,5 тыс. кв. м в непосредственной близости от будущего комплекса университетских зданий. Средства на строительство школы в объеме 1670 тыс. руб. министерство передало Волгоградскому горисполкому (как заказчику) с народно-хозяйственным планом на 1978-1980 годы [14]. Ввод школьного здания в эксплуатацию планировался на 1 сентября 1979 года. Успешное завершение строительства и оснащение этого здания университетским оборудованием позволяло начать учебный процесс по университетской программе с 1 сентя6ря 1980 года.

С целью ускорения создания материальной базы университета, оснащения строящегося школьного здания соответствующим оборудованием, своевременной подготовки и под- 
бора педагогических кадров и комплектования библиотеки председатель исполкома облсовета 29 апреля 1979 г. Ю.И. Ломакин попросил Совет Министров РСФСР разрешить организовать в мае 1979 г. ректорскую группу Волгоградского университета в составе 6 человек (проректор по учебной и научной работе, проректор по административно-хозяйственной работе, инженер, старший библиотекарь, секретарь и шофер) [32].

8 мая 1979 г. В.И. Кочемасов направил письмо Ю.И. Ломакина министру финансов РСФСР А.А. Бобровникову и министру высшего и среднего специального образования РСФСР И.Ф. Образцову с указанием: «Прошу рассмотреть и о результатах доложить» [37].

16 мая А.А. Бобровников и И.Ф. Образцов в своем письме в Совет Министров РСФСР не согласились с предложением Ю.И. Ломакина. Ссылаясь на то, что «организация Волгоградского государственного университета и укомплектование его преподавательскими кадрами предусмотрены в 1980 г.», они «полагали бы возможным разрешить организацию указанной группы в количестве 5 человек (проректор по учебной и научной работе, проректор по административно-хозяйственной работе, инженер, старший библиотекарь, секретарь) с 1 октября 1979 года» [31].

18 мая Совет Министров РСФСР дал свое согласие на организацию ректорской группы [44]. 5 июня министр высшего и среднего специального образования РСФСР И.Ф. Образцов подписал приказ о создании с 1 октября 1979 г. ректорской группы Волгоградского университета в количестве 5 человек [1, с. 34]. За пять дней до выхода приказа 31 мая коллегия Минвуза РСФСР приняла решение о начале занятий в Волгоградском госуниверситете с 1 сентября 1980 года [42, с. 355].

Между тем строительство школьного здания затягивалось. 12 февраля 1980 г. вопрос «О мерах по своевременному открытию и дальнейшему развитию Волгоградского государственного университета» был рассмотрен на заседании бюро областного комитета КПСС [6]. В принятом постановлении отмечалось: «Считать строительство комплекса зданий Волгоградского государственного университета важнейшей стройкой области. Обязать облисполком (т. Мальченко), Волгоград- ский горисполком (т. Атопов), Главнижневолжскстрой (т. Опейкин) принять необходимые меры по обеспечению ввода в действие строящегося учебного здания университета (школы) к 1 мая 1980 г., студенческого общежития - к 1 июня 1982 г., учебно-лабораторного корпуса полезной площадью 16 тыс. кв. м и столовой к 1 июня 1983 г.». Волгоградскому горисполкому было поручено решить ряд вопросов: до 1 марта 1980 г. о размещении административно-управленческого аппарата открываемого университета; совместно с руководством энергетического техникума о предоставлении в 1980 г. 200 мест для студентов университета; о выделении до 1985 г. для научно-педагогических кадров, имеющих ученые степени и звания, приглашенных из других городов страны, 2500 кв. м полезной площади в соответствии с потребностями развития университета за счет долевого участия предприятий города. Ректорская группа под руководством М.M. Загорулько ${ }^{2}$ обязывалась к 1 августа 1980 г. укомплектовать университет преподавательскими кадрами на 1980/81 учебный год. В этом вопросе необходимую помощь должен был оказывать Волгоградский горком КПСС. Облисполкому и ректорам высших учебных заведений города поручалось оказать содействие в обеспечении университета учебной и научно-технической литературой. Облкниготорг обязывался обеспечить комплектование научной библиотеки университета.

Для своевременного строительства университета обком КПСС просил Совет Министров РСФСР, Министерства высшего и среднего специального образования СССР и РСФСР, Минпромстрой СССР и Госплан РСФСР: выделить для обеспечения ввода первой очереди капитальные вложения в объеме 8,3 млн руб. (1981 г. - 2,5 млн, 1982 г. 2,8 млн, 1983 г. - 3,0 млн); обязать государственный союзный институт по проектированию высших учебных заведений завершить разработку технической документации на первую очередь строительства университета в 1980 г.; определить структуру специальностей университета с учетом потребностей народного хозяйства; выделить университету необходимый транспорт. Все определенные постановлением структуры обязывались информи- 
ровать секретариат обкома КПСС о выполнении постановления 1 января и 1 июля каждого года.

Через месяц 14 марта 1980 г. вопрос «О мероприятиях по ускорению строительства Волгоградского государственного университета и подготовке его к первому приему студентов в 1980 г.» был рассмотрен на заседании бюро Волгоградского городского комитета КПСС [8]. В целях выполнения постановления бюро обкома КПСС от 12 февраля бюро горкома КПСС утвердило мероприятия по ускорению строительства университета и подготовке его к первому приему студентов в 1980 году. Строительство ставилось под контроль партийных органов заказчика и субподрядных организаций. Мероприятия предусматривали развертывание на объектах строительства социалистического соревнования, увеличение количества рабочих, своевременное выделение в необходимых объемах материально-технических ресурсов. Наряду с мерами, определенными постановлением бюро обкома КПСС и включенными в план мероприятий, бюро горкома КПСС обязало горисполком до 1 сентября 1980 г. выделить 200 кв. м жилой площади для научно-педагогических кадров университета и в мае - июне того же года обеспечить помощь предприятий и вузов города в оборудовании и оснащении учебных аудиторий, кабинетов и помещений университета.

В конце июля 1980 г. заместитель заведующего отделом пропаганды и агитации А. Ермаков и заведующий отделом строительства и городского хозяйства Ю. Сахаров проинформировали руководство горкома о ходе выполнения постановления бюро Волгоградского горкома КПСС от 14 марта [3]. Представленная информация свидетельствовала о том, что ввести в действие здание школы к 1 мая не успели. В июле оно было только подготовлено к вводу в эксплуатацию. Государственная комиссия примет здание в эксплуатацию и передаст на баланс университета позднее, 1 августа 1980 года. По другим направлениям работы результаты оказались лучше. Министерство высшего и среднего специального образования РСФСР утвердило структуру университета на первый год обучения. Для обеспечения учебного процесса была достигнута договоренность на замещение 70 \% вакантных должностей профессорско-преподавательского состава. Из Воронежского, Саратовского и Куйбышевского университетов, вузов Волгограда пригласили профессоров и ведущих доцентов для чтения отдельных курсов на условиях почасовой оплаты. Решением исполкома горсовета от 24 марта 1980 г. для научно-педагогических кадров выделили 195 кв. м жилой площади. Был выполнен ряд других мероприятий. Библиотечный фонд университета в июле насчитывал уже 5000 книг. Организованно и в срок начала работать приемная комиссия, которая на 21 июля приняла 565 заявлений абитуриентов.

В 1980 г. Волгоградский государственный университет осуществил прием 250 студентов на первый курс дневного отделения по пяти специальностям: «Русский язык и литература», «Романо-германские языки и литература», «История», «Математика», «Физика» (по 50 чел. на каждую).

Руководство города и области возлагали на университет большие надежды. Уже в декабре 1980 г. секретарь обкома КПСС Л.С. Куличенко и председатель исполкома облсовета Ю.И. Ломакин направили на имя министра высшего и среднего специального образования РСФСР И.Ф. Образцова письмо, в котором просили утвердить университету план приема по годам и формам обучения на XI пятилетку [5]. Руководители области просили уже в 1981 г. открыть в университете подготовку по вечерней и заочной формам обучения (1981 г. - по 100 человек, с 1982 по 1985 г. - по 150 человек по каждой форме). Прием на дневную форму обучения предлагалось увеличить и довести в 1981 г. до 500, а с 1982 по 1985 г. - до 600 человек. При этом наряду с уже открытыми пятью специальностями предлагалось начать подготовку в 1981 г. еще по трем («Правоведение», «Экономическая кибернетика» и «Организация механизированной обработки экономической информации»), a c 1982 г. - по двум («Химия», «Биология»).

Однако эти планы для только что открытого университета, не имеющего соответствующей материальной базы, были нереальны. В 1981 г. Волгоградский государственный университет произвел первый прием на вечернее 
(85 чел.) и в 1982 г. на заочное (100 чел.) отделения по специальностям «Русский язык и литература» и «История». Обучение стало вестись на всех трех отделениях. Из пяти намеченных к открытию специальностей в первое десятилетие работы университета будет открыта только одна - «Правоведение», и произойдет это лишь в 1986 году [42, с. 230, 238].

В первые годы университет испытывал большие трудности с материальной базой. В 1980/81-1982/83 учебных годах Волгоградским исполкомом горсовета выделено 300 мест в общежитии для размещения иногородних студентов университета, а также 20 квартир для профессорско-преподавательского состава.

Минвуз РСФСР разработал и осуществил план мероприятий по оказанию помощи Волгоградскому университету со стороны Саратовского, Воронежского и Ростовского университетов. Этим планом предусматривались организация учебных лабораторий (кабинетов) по физике, математике, иностранным языкам, помощь в комплектовании библиотеки справочной литературой, учебными пособиями, методическими разработками и т. п., помощь в подготовке и организации приема студентов на первый курс, издание учебных пособий, монографий, командирование опытных преподавателей для чтения лекций и проведения семинаров.

Со строительством комплекса зданий университета все было еще сложнее. Минвуз РСФСР в плане на 1980 г. заявило Минпромстрою СССР начало строительства комплекса университета, однако последний с этим не согласился, его поддержал и Госплан РСФСР.

В 1981 г. на площадке строительства комплекса осуществлялись лишь подготовительные работы. При плане 0,5 млн руб. освоение составило 0,25 млн руб. строительномонтажных работ.

Только в 1982 г. Министерство приступило к строительству комплекса зданий университета. При плане строительно-монтажных работ в 1 млн руб. было освоено всего 0,46 млн рублей. Минпромстрой СССР в 1983 г. на строительстве университета должен был освоить 1 млн руб. и в IV квартале ввести в эксплуатацию блок учебного корпуса площадью 4,5 тыс. кв. метров.
Строительство здания общежития университета на 1085 мест сметной стоимостью 2,3 млн руб. началось раньше - в 1978 году. Из выделенных к 1983 г. 1,5 млн руб. Минпромстрой СССР освоил только 0,88 млн рублей. На 1983 г. выделили 0,4 млн рублей. Ввод общежития в строй должен был состояться в 1985 году.

Такое положение с отставанием темпов строительства не могло быть терпимым. 10 марта 1983 г. министр высшего и среднего специального образования РСФСР И.Ф. Образцов направил соответствующую информацию в Совмин РСФСР [14]. Уже 16 марта последовало распоряжение заместителя председателя Совмина РСФСР В.И. Кочемасова в адрес председателя Волгоградского исполкома облсовета Ю.И. Ломакина с требованием принять меры по освоению капвложений на объектах университета [38].

Вопрос о развитии молодого университета несколько лет находился на постоянном контроле Совета Министров РСФСР. Лишь 24 марта 1986 г. заведующий отделом высшего, среднего и профессионально-технического образования Совмина РСФСР Н. Андрианов подготовил для руководства справку о целесообразности снятия с контроля постановления № 561. В справке говорилось «В соответствии с постановлением Совета Министров РСФСР от 21 октября 1974 г. № 561 "Об организации в г. Волгограде государственного университета" Минвуз РСФСР организовал в 1980 г. Волгоградский университет». Н. Андрианов считал целесообразным снять с контроля указанное постановление. В тот же день разрешение было получено [46]. К этому времени университет готовился ко второму выпуску молодых специалистов.

Результаты. Подводя итоги, мы можем сделать вывод, что процесс воплощения в жизнь идеи создания в Волгограде государственного университета затянулся на долгих 9 лет, три года из которых ушло на подготовку решения Секретариата ЦК КПСС, Совмина СССР и Совмина РСФСР и 6 лет на решение организационных вопросов и создание необходимой учебно-материальной базы (типовое здание школы) для проведения первого набора студентов. Довольно длительный срок. Например, от принятия постановления Совми- 
на РСФСР в октябре 1974 г. до открытия Челябинского государственного университета в 1976 г. прошло два года [46]. Да и возведение университетских корпусов затягивалось. Только в 1982 г. Министерство приступило к строительству основного комплекса зданий университета, первый корпус которого был сдан в эксплуатацию в 1983 году.

\section{ПРИМЕЧАНИЯ}

\begin{abstract}
${ }^{1}$ Так в документе, правильно - в Краснооктябрьском районе города.

${ }^{2} 23$ января 1980 г. Загорулько Максим Матвеевич приказом министра просвещения РСФСР А.И. Данилова был освобожден от обязанностей ректора Волгоградского государственного педагогического института им. А.С. Серафимовича в порядке перевода на другую работу и приказом Минвуза РСФСР назначен на должность проректора по учебной и научной работе Волгоградского государственного университета. 21 марта приказом Минвуза РСФСР № 110-4 он будет освобожден от этой должности и другим приказом № 7-ГУ от того же числа назначен ректором Волгоградского государственного университета [1, с. 35,36 ; 42, с. 355$]$.

${ }^{3}$ См. пункт 15 в списке литературы. Ксерокопия подлинника постановления Секретариата ЦК КПСС № СТ 93/6с от 21.08.1973 г. «Об организации Государственного университета в г. Волгограде» предоставлена ректору ВолГУ В.В. Тараканову директором Российского государственного архива новейшей истории Н.Г. Томилиным (письмо от 04.10.2017 г. № 6/242/2017).
\end{abstract}

\section{СПИСОК ЛИТЕРАТУРЫ}

1. Вестник Волгоградского государственного университета. Серия 6, Университетское образование. - 2004. - Вып. 7. - 162 с.

2. Вестник Волгоградского государственного университета. Юбилейный выпуск. Воспоминания. Мечты сбываются... -2010. - 133 с.

3. Информация о ходе выполнения постановления бюро горкома КПСС от 14 марта 1980 г. № 35/5 «О мероприятиях по ускорению строительства Волгоградского университета и подготовке его к первому приему студентов в 1980 г.». Не ранее 21 июля и не позднее 28 июля 1980 г. // Центр документации новейшей истории Волгоградской области (далее ЦДНИВО). - Ф. 71. - Оп. 57. - Д. 27. - Л. 7-8.

4. Мгновения, события, поступки: из истории становления Волгоградского государствен- ного университета / под ред. Р. Л. Ковалевского, А. Г. Морозова, А. С. Скрипкина. - Волгоград : Крутон, 2016. - 304 с.

5. О контингенте студентов Волгоградского государственного университета. Письмо секретаря обкома КПСС и председателя исполкома облсовета от 17 декабря 1980 г. министру высшего и среднего специального образования РСФСР // ЦДНИВО. Ф. 113. - ОП. 110. - Д. 109. - Л. 9-11.

6. О мерах по своевременному открытию и дальнейшему развитию Волгоградского государственного университета. Протокол № 37 заседания бюро Волгоградского обкома КПСС от 12 февраля 1980 г. // ЦДНИВО. - Ф. 113. - Оп. 110. - Д. 25. Л. 64-65, 95-97.

7. О мерах по подготовке к открытию Волгоградского государственного университета. Выписка из решения исполкома Волгоградского облсовета депутатов трудящихся от 23 января 1974 г. № 2/45 // Государственный архив Российской Федерации (далее ГАРФ). - Ф. А-605. - ОП. 1. - Д. 6217. - Л. 143-144.

8. О мероприятиях по ускорению строительства Волгоградского университета и подготовке его к первому приему студентов в 1980 г. Протокол № 35 заседания бюро горкома КПСС от 14 марта 1980 г. // ЦДНИВО. - Ф. 71. - Оп. 57. - Д. 33. - Л. 62, 67-68, 79-81.

9. О преобразовании Волгоградского политехнического института в Государственный университет. Письмо первого секретаря Волгоградского обкома КПСС от 21 июля 1971 г. в ЦК КПСС // ЦДНИВО. Ф. 113. -Оп. 83. - Д. 93. - Л. 17-23.

10. О проектировании учебно-лабораторных зданий Волгоградского государственного университета. Письмо председателя Госплана РСФСР в Совет Министров РСФСР от 27 ноября 1973 г. // ГАРФ. - Ф. А-259. - Оп. 46. - Д. 4699. - Л. 31.

11. О создании учебно-материальной базы университета в г. Волгограде и о сроках его открытия. Письмо В. Кочемасова от 26 июня 1974 г. // ГАРФ. - Ф. А-259. - ОП. 46. - Д. 4699. - Л. 20.

12. О создании учебно-материальной базы университета в г. Волгограде и о сроках его открытия. Письмо председателя исполкома Волгоградского областного совета депутатов трудящихся в Совет Министров РСФСР от 12.09.1974 г. // ГАРФ. Ф. А-259. - Оп. 46. - Д. 4699. - Л. 18-19.

13. О создании учебно-материальной базы университета в г. Волгограде и о сроках его открытия. Письмо заместителя председателя Госплана РСФСР и министра высшего и среднего специального образования РСФСР от 30.09.1974 г. // ГАРФ. Ф. А-259. - ОП. 46. - Д. 4699. - Л. 15-16.

14. О ходе выполнения постановления Совета Министров РСФСР от 21.10.1974 г. № 561 «Об организации в г. Волгограде государственного универ- 
ситета». Письмо Минвуза РСФСР № 24-32-62ин/240-3 от 10.03.1983 г. // ГАРФ. - Ф. А-259. - Оп. 46. Д. 4699. - Л. 3-5.

15. Об организации Государственного университета в г. Волгограде. Постановление Секретариата ЦК КПСС № СТ 93/6с от 21.08.1973 г. // Российский государственный архив новейшей истории (РГАНИ) ${ }^{3}$.

16. Об организации в г. Волгограде Государственного университета. Проект постановления Совета Министров СССР от октября 1973 г. // ГАРФ. - Ф. А-259. - Оп. 46. - Д. 4699. - Л. 30.

17. Об организации в г. Волгограде Государственного университета. Письмо секретаря обкома КПСС и председателя исполкома облсовета в Совет Министров РСФСР от 5 ноября 1973 г. // ГАРФ. - Ф. А-259. - ОП. 46. - Д. 4699. - Л. 33.

18. Об организации в г. Волгограде Государственного университета. Письмо председателя Coвмина РСФСР и министра высшего и среднего специального образования СССР в Совет Министров СССР от ноября 1973 г. // ГАРФ. - Ф. А-259. Оп. 46. - Д. 4699. - Л. 27-29.

19. Об организации Волгоградского государственного университета. Проект постановления Совета Министров СССР от ноября 1973 г. //ГАРФ. - Ф. А-259. - Оп. 46. - Д. 4699. - Л. 26; Копии: Ф. 5446. - Оп. 108. - Д. 1091. - Л. 3; Ф.9606. Оп. 1. - Д. $6010 .-$ Л. 84.

20. Об организации в г. Волгограде Государственного университета. Письмо председателя Совмина РСФСР и министра высшего и среднего специального образования СССР в Совет Министров СССР от 21 января 1974 г. // ГАРФ. - Ф. А-259. Оп. 46. - Д. 4699. - Л. 24-25; Копии: Ф. 5446. Оп. 108. - Д. 1091. - Л. 1-2; Ф. 9606. - Оп. 1. Д. 6010. - Л. 82-83.

21. Об организации Волгоградского университета. Письмо зам. председателя Госплана СССР в Совет Министров СССР от 15 февраля 1974 г. № 225-17 // ГАРФ. -Ф. 5446. - Оп. 108. - Д. 1091. -Л. 5.

22. Об организации Волгоградского государственного университета. Заключение зам. министра финансов СССР от 26 февраля 1974 г. // ГАРФ. Ф. 5446. - Оп. 108. - Д. 1091. - Л. 6.

23. Об организации Волгоградского государственного университета. Справка Управления делами Совмина с замечаниями (непозднее 1 марта 1974 г.) // ГАРФ. - Ф. 5446. - ОП. 108. - Д. 1091. - Л. 14-15.

24. Об организации Волгоградского государственного университета. Справка ст. референта Управления Делами Совмина СССР от 23 мая 1974 г. к вопросу // ГАРФ. - Ф. 5446. - Оп. 108. - Д. 1091. Л. 9-10; Копия: Ф. 9606. - Оп. 1. - Д. 6010. - Л. 78-81.

25. Об организации Волгоградского государственного университета. Письмо министра высшего и среднего специального образования СССР в Совет
Министров СССР от 17 июня 1974 г. № 90-01-245/02 // ГАРФ. - Ф. 5446. - Оп. 108. - Д. 1091. - Л. 11-12; Копия: Ф. 9606. - Оп. 1. - Д. 6010. - Л. 75-76.

26. Об организации Волгоградского государственного университета. Проект постановления Совета Министров СССР от 17 июня 1974 г. // ГАРФ. - Ф. 5446. - ОП. 108. - Д. 1091. - Л. 13; Копия: Ф. 9606. - Оп. 1. - Д. 6010. - Л. 77.

27. Об организации Волгоградского государственного университета. Выписка из протокола заседания Президиума Совета Министров СССР от 19 июня 1974 г. № 25 // ГАРФ. - Ф. А-259. - Оп. 46. Д. 4699. - Л. 21.

28. Об организации Волгоградского университета. Письмо министра просвещения СССР в Совет Министров СССР от 26 февраля 1974 г. // ГАРФ. - Ф. 5446. - ОП. 108. - Д. 1091. - Л. 7.

29. Об организации в г. Волгограде Государственного университета. Постановление Совета Министров СССР от 21.06.1974 г. № 510 // ГАРФ. Ф. 5446. - Оп. 1. - Д. 877. - Л. 129.

30. Об организации в г. Волгограде Государственного университета. Постановление Совета Министров РСФСР от 21 октября 1974 г. № 561 // ГАРФ. - Ф. А-259. - ОП. 1. - Д. 3161. - Л. 35; Копия: Оп. 46. - Д. 4699. - Л. 12.

31. Об организации ректорской группы Волгоградского университета. Письмо министра финансов РСФСР и министра высшего и среднего специального образования РСФСР от 16.05.1979 г. // ГАРФ. - Ф. А-259. - Оп. 46. - Д. 4699. - Л. 7.

32. Об организации ректорской группы Волгоградского университета. Письмо председателя исполкома Волгоградского областного совета народных депугатов в Совет Министров РСФСР от 29.04.1979 № 0616м/348 // ГАРФ. - Ф. А-259. - Оп. 46. - Д. 4699. - Л. 9.

33. Об организации университета в г. Волгограде. Справка зав. отделом высшего, среднего и профессионально-технического образования от 19 июня 1974 г. // ГАРФ. - Ф. А-259. - Оп. 46. Д. 4699. - Л. 22-23.

34. Поручение В. Кочемасова от 17 сентября 1974 г. // ГАРФ. - Ф. А-259. - Оп. 46. - Д. 4699. - Л. 17.

35. Поручение Н. Тихонова от 28 января 1974 г. // ГАРФ. - Ф. 5446. - Оп. 108. - Д. 1091. - Л. 4.

36. Постановление ЦК КПСС от 21 августа 1973 г. «Об организации Государственного университета в г. Волгограде». Протокол № 92 заседания бюро Волгоградского обкома КПСС от 24 сентября 1973 г. // ЦДНИВО. - Ф. 113. - Оп. 89. - Д. 23. - Л. 58-59. 37. Распоряжение В. Кочемасова от 8 мая 1979 г. // ГАРФ. - Ф. А-259. - Оп. 46. - Д. 4699. - Л. 8. 38. Распоряжение В. Кочемасова от 16 марта 1983 г. // ГАРФ. - Ф. А-259. - Оп. 46. - Д. 4699. - Л. 2. 39. Распоряжение К. Мазурова от 1 марта 1974 г. // ГАРФ. - Ф. 5446. - Оп. 108. - Д. 1091. - Л. 8. 
40. Распоряжение М.С. Соломенцева от 11 ноября 1973 г. // ГАРФ. - Ф. А-259. - Оп. 46. Д. 4699. - Л. 32.

41. Сидоров, С. Г. Волгоградский государственный университет. Люди. События. Факты. 1980-1999 / С. Г. Сидоров. - Волгоград : Изд-во ВолГУ, 2000. - 260 с.

42. Сидоров, С. Г. Волгоградскому государственномууниверситету-25 лет, 1980-2005 / С. Г. Сидоров. - Волгоград : Изд-во ВолГУ, 2005. - 399 с.

43. Сидоров, С. Г. К истории Волгоградского государственного университета. 1980-1995 : стат. справ. / С. Г. Сидоров. - Волгоград : Изд-во ВолГУ, 1996. $-136 \mathrm{c}$.

44. Согласие Совета Министров РСФСР от 18.05.1979 г. об организации ректорской группы Волгоградского университета // ГАРФ. - Ф. А-259. Оп. 46. - Д. 4699. - Л. 6.

45. Справка (не позднее 1 марта 1974 г.) // ГАРФ. - Ф. 5446. - ОП. 108. - Д. 1091. - Л. 17.

46. Справка зав. отделом высшего, среднего и профессионально-технического образования от 24 марта 1986 г. // ГАРФ. - Ф. А-259. - Оп. 46. Д. 4699. - Л. 1.

47. Справка зав. отделом высшего, среднего и профессионально-технического образования от 15 октября 1974 г. // ГАРФ. - Ф. А-259. - ОП. 46. Д. 4699. - Л. 14.

48. Справка зав. отделом высшего, среднего и профессионально-технического образования от 17 октября 1974 г. // ГАРФ. - Ф. А-259. - Оп. 46. Д. 4699. - Л. 13.

49. Справка-информация зав. отделом высшего, среднего и профессионально-технического образования от 23 марта 1979 г. о ходе выполнения Минвузом РСФСР постановления Совета Министров РСФСР № 561 «Об организации в г. Волгограде государственного университета» // ГАРФ. Ф. А-259. - Оп. 46. - Д. 4699. - Л. 10-11.

\section{REFERENCES}

1. Vestnik Volgogradskogo gosudarstvennogo universiteta. Seriya 6. Universitetskoe obrazovanie [Science Journal of Volgograd State University. University Education], 2004, iss. 7. 162 p.

2. Vestnik Volgogradskogo gosudarstvennogo universiteta. Yubileynyy vypusk. Vospominaniya. Mechty sbyvayutsya... [Science Journal of Volgograd State University. Festive Publication. Memoirs...], 2010. 133 p.

3. Informatsiya o khode vypolneniya postanovleniya byuro gorkoma KPSS ot 14 marta $1980 \mathrm{~g}$. № 35/5 «O meropriyatiyakh po uskoreniyu stroitelstva Volgogradskogo universiteta i podgotovke ego $\mathrm{k}$ pervomu priemu studentov v 1980 g.»». Ne ranee 21 iyulya i ne pozdnee 28 iyulya $1980 \mathrm{~g}$. [Information on the Implementation of the Resolution of the Bureau of the CPSU City Committee of March 14, 1980 no. 35/5 "About Measures to Accelerate the Construction of Volgograd University and Prepare It for the First Student Admission in 1980". Not Earlier Than July 21 and not Later Than July 28, 1980]. Tsentr dokumentatsii noveyshey istorii Volgogradskoy oblasti (dalee - TsDNIVO) [Center of Recent History Documentation of Volgograd Region], F. 71, Op. 57, D. 27, L. 7-8.

4. Kovalevskiy R.L., Morozov A.G., Skripkin A.S., eds. Mgnoveniya, sobytiya postupki: iz istorii stanovleniya Volgogradskogo gosudarstvennogo universiteta [Moments, Events, Deeds: From the History of the Formation of Volgograd State University]. Volgograd, Kruton Publ., 2016. 304 p.

5. O kontingente studentov Volgogradskogo gosudarstvennogo universiteta. Pismo sekretarya obkoma KPSS i predsedatelya ispolkoma oblsoveta ot 17 dekabrya 1980 g. ministru vysshego i srednego spetsialnogo obrazovaniya RSFSR [On the Student Body of Volgograd State University. Letter Dated 17 December 1980 from the Secretary of the CPSU Regional Committee and the Chairman of the Executive Committee of the Regional Council to the Minister of Higher and Secondary Special Education of the RSFSR]. TsDNIVO [Center of Recent History Documentation of Volgograd Region], F. 113, Op. 110, D. 109, L. 9-11.

6. O merakh po svoevremennomu otkrytiyu i dalneyshemu razvitiyu Volgogradskogo gosudarstvennogo universiteta. Protokol № 37 zasedaniya byuro Volgogradskogo obkoma KPSS ot 12 fevralya $1980 \mathrm{~g}$. [On Measures for the Timely Opening and Further Development of Volgograd State University. Protocol no. 37 of the Meeting of the Bureau of the CPSU Volgograd Regional Committee of February 12, 1980]. Ts DNIVO [Center of Recent History Documentation of Volgograd Region], F. 113, Op. 110, D. 25, L. 64-65, 95-97.

7. O merakh po podgotovke k otkrytiyu Volgogradskogo gosudarstvennogo universiteta. Vypiska iz resheniya ispolkoma Volgogradskogo oblsoveta deputatov trudyashchikhsya ot 23 yanvarya 1974 g. № 2/45 [On Measures to Prepare the Opening of Volgograd State University. Extract from the Decision of the Executive Committee of the Volgograd Regional Council of Workers' Deputies Dated January 23, 1974 no. 2/45]. GARF Gosudarstvennyy arkhiv Rossiyskoy Federatsii (dalee-GARF) [State Archive of the Russian Federation], F. A-605, Op. 1, D. 6217, L. 143-144.

8. O meropriyatiyakh po uskoreniyu stroitelstva Volgogradskogo universiteta i podgotovke ego $\mathrm{k}$ pervomu priemu studentov v 1980 g. Protokol № 35 zasedaniya byuro gorkoma KPSS ot 14 marta $1980 \mathrm{~g}$. [About Measures to Accelerate the Construction of 
Volgograd University and Prepare It for the First Student Admission in 1980. Protocol no. 35 of the Meeting of the Bureau of the CPSU City Committee of March 14, 1980]. TsDNIVO [Center of Recent History Documentation of Volgograd Region], F. 71, Op. 57, D. 33, L. 62, 67-68, 79-81.

9. O preobrazovanii Volgogradskogo politekhnicheskogo instituta v Gosudarstvennyy universitet. Pismo pervogo sekretarya Volgogradskogo obkoma KPSS ot 21 iyulya 1971 g. v TsK KPSS [On the Transformation of Volgograd Polytechnic Institute into State University. Letter Dated July 21, 1971 from the First Secretary of the CPSU Volgograd Regional Committee to the Central Committee of the CPSU]. TsDNIVO [Center of Recent History Documentation of Volgograd Region], F. 113, Op. 83, D. 93, L. 17-23.

10. O proektirovanii uchebno-laboratornykh zdaniy Volgogradskogo gosudarstvennogo universiteta. Pismo predsedatelya Gosplana RSFSR v Sovet Ministrov RSFSR ot 27 noyabrya 1973 g. [On the Design of Educational and Laboratory Buildings of Volgograd State University. Letter from the Chairman of the State Planning Commission of the RSFSR to the Council of Ministers of the RSFSR of November 27, 1973]. GARF [State Archive of the Russian Federation], F. A-259, Op. 46, D. 4699, L. 31.

11. O sozdanii uchebno-materialnoy bazy universiteta $\mathrm{v}$ g. Volgograde i o srokakh ego otkrytiya. Pismo V. Kochemasova ot 26 iyunya 1974 g. [On the Creation of the Educational Resources and Facilities of the University in Volgograd and on the Timing of Its Opening. Letter from V. Kochemasov Dated June 26, 1974]. GARF [State Archive of the Russian Federation], F. A-259, Op. 46, D. 4699, L. 20.

12. O sozdanii uchebno-materialnoy bazy universiteta $\mathrm{v}$ g. Volgograde i o srokakh ego otkrytiya. Pismo predsedatelya ispolkoma Volgogradskogo oblastnogo soveta deputatov trudyashchikhsya $\mathrm{v}$ Sovet Ministrov RSFSR ot 12.09.1974 g. [On the Creation of the Educational Resources and Facilities of the University in Volgograd and on the Timing of Its Opening. Letter from the Chairman of the Executive Committee of the Volgograd Regional Council of Workers' Deputies to the Council of Ministers of the RSFSR of September 12, 1974]. GARF [State Archive of the Russian Federation], F. A-259, Op. 46, D. 4699, L. 18-19.

13. O sozdanii uchebno-materialnoy bazy universiteta v g. Volgograde i o srokakh ego otkrytiya. Pismo zamestitelya predsedatelya Gosplana RSFSR i ministra vysshego i srednego spetsialnogo obrazovaniya RSFSR ot 30.09.1974 g. [On the Creation of the Educational Resources and Facilities of the University in Volgograd and on the Timing of Its Opening. Letter of the Deputy Chairman of the State Planning Commission of the RSFSR and the Minister of Higher and Secondary Special Education of the RSFSR of September 30, 1974]. GARF [State Archive of the Russian Federation], F. A-259, Op. 46, D. 4699, L. 15-16.

14. O khode vypolneniya postanovleniya Soveta Ministrov RSFSR ot 21.10.1974 g № 561 «Ob organizatsii v g. Volgograde gosudarstvennogo universiteta». Pismo Minvuza RSFSR № 24-32-62in/ 24-0-3 ot 10.03.1983 g. [On the Implementation of the Decree of the Council of Ministers of the RSFSR of October 21, 1974 no. 561 "On Establishing a State University in Volgograd." Letter of the Ministry of Higher Education of the RSFSR no. 24-32-62ин/24-0-3 of March 10, 1983]. GARF [State Archive of the Russian Federation], F. A-259, Op. 46, D. 4699, L. 3-5.

15. Ob organizatsii Gosudarstvennogo universiteta v g. Volgograde. Postanovlenie Sekretariata TsK KPSS № ST 93/6s ot 21.08.1973 g. [On Establishing the State University in Volgograd. Resolution of the Secretariat of the the CPSU Central Committee no. CT 93/6c Dated August 21,1973]. Rossiyskiy gosudarstvennyy arkhiv noveyshey istorii (dalee - RGANI) [Russian State Archive of Recent History].

16. $\mathrm{Ob}$ organizatsii v g. Volgograde Gosudarstvennogo universiteta. Proekt postanovleniya Soveta Ministrov SSSR ot oktyabrya 1973 g. [On Establishing the State University in Volgograd. Draft Resolution of the Council of Ministers of the USSR of October 1973]. GARF [State Archive of the Russian Federation], F. A-259, Op. 46, D. 4699, L. 30.

$17 . \mathrm{Ob}$ organizatsii $\mathrm{v}$ g. Volgograde Gosudarstvennogo universiteta. Pismo sekretarya obkoma KPSS i predsedatelya ispolkoma oblsoveta V Sovet Ministrov RSFSR ot 5 noyabrya 1973 g. [On Establishing the State University in Volgograd. Letter from the Secretary of the Regional Committee of the CPSU and the Chairman of the Executive Committee of the Regional Council to the Council of Ministers of the RSFSR of November 5, 1973]. GARF [State Archive of the Russian Federation], F. A-259, Op. 46, D. 4699, L. 33.

18 . Ob organizatsii v g. Volgograde Gosudarstvennogo universiteta. Pismo predsedatelya Sovmina RSFSR i ministra vysshego i srednego spetsialnogo obrazovaniya SSSR v Sovet Ministrov SSSR ot noyabrya 1973 g. [On Establishing the State University in Volgograd. Letter from the Chairman of the Council of Ministers of the RSFSR and the Minister of Higher and Secondary Special Education of the USSR to the Council of Ministers of the USSR of November 1973]. GARF [State Archive of the Russian Federation], F. A-259, Op. 46, D. 4699, L. 27-29.

19. $\mathrm{Ob}$ organizatsii Volgogradskogo gosudarstvennogo universiteta. Proekt postanovleniya Soveta Ministrov SSSR ot noyabrya 1973 g. [On Establishing Volgograd State University. Draft 
Resolution of the Council of Ministers of the USSR of November 1973]. GARF [State Archive of the Russian Federation], F. A-259, Op. 46, D. 4699, L. 26; Copies: F. 5446, Op. 108, D. 1091, L. 3; F.9606, Op. 1, D. 6010,L. 84. 20. Ob organizatsii v g. Volgograde Gosudarstvennogo universiteta. Pismo predsedatelya Sovmina RSFSR i ministra vysshego i srednego spetsialnogo obrazovaniya SSSR v Sovet Ministrov SSSR ot 21 yanvarya 1974 g. [On Establishing a State University in Volgograd. Letter from the Chairman of the Council of Ministers of the RSFSR and the Minister of Higher and Secondary Special Education of the USSR to the Council of Ministers of the USSR of January 21, 1974]. GARF [State Archive of the Russian Federation], F. A-259, Op. 46, D. 4699, L. 24-25; Copies: F. 5446, Op. 108, D. 1091, L. 1-2; F. 9606, Op. 1, D. 6010, L. 82-83.

21. Ob organizatsii Volgogradskogo universiteta. Pismo zam. predsedatelya Gosplana SSSR v Sovet Ministrov SSSR ot 15 fevralya 1974 g. № 225-17 [On Establishing Volgograd University. Letter to the Deputy Chairman of the State Planning Commission of the USSR to the Council of Ministers of the USSR of February 15, 1974 no. 225-17]. GARF [State Archive of the Russian Federation], F. 5446, Op. 108, D. 1091, L. 5.

22. Ob organizatsii Volgogradskogo gosudarstvennogo universiteta. Zaklyuchenie zam. ministra finansov SSSR ot 26 fevralya $1974 \mathrm{~g}$. [On Establishing Volgograd State University. Conclusion of the Deputy Minister of Finance of the USSR of February 26, 1974]. GARF [State Archive of the Russian Federation], F. 5446, Op. 108, D. 1091, L. 6.

23. Ob organizatsii Volgogradskogo gosudarstvennogo universiteta. Spravka Upravleniya delami Sovmina s zamechaniya (ne pozdnee 1 marta 1974 g.) [On Establishing Volgograd State University. Certificate from the Office of the Council of Ministers with Comments (No Later Than March 1, 1974)]. GARF [State Archive of the Russian Federation], F. 5446, Op. 108, D. 1091, L. 14-15.

24. $\mathrm{Ob}$ organizatsii Volgogradskogo gosudarstvennogo universiteta. Spravka st. referenta Upravleniya Delami Sovmina SSSR ot 23 maya 1974 g. $\mathrm{k}$ voprosu [On Establishing Volgograd State University. Certificate of Senior Referent of the Administration of the Council of Ministers of the USSR of May 23, 1974 to the Issue]. GARF [State Archive of the Russian Federation], F. 5446, Op. 108, D. 1091, L. 9-10; Copies: F. 9606, Op. 1, D. 6010, L. 78-81.

25. Ob organizatsii Volgogradskogo gosudarstvennogo universiteta. Pismo ministra vysshego i srednego spetsialnogo obrazovaniya SSSR v Sovet Ministrov SSSR ot 17 iyunya 1974 g. № 90-01245/02 [On Establishing Volgograd State University. Letter of the USSR Minister of Higher and Secondary Special Education to the Council of Ministers of the
USSR Dated June 17, 1974 no. 90-01-245 / 02]. GARF [State Archive of the Russian Federation], F. 5446, Op. 108, D. 1091, L. 11-12; Copies: F. 9606, Op. 1, D. 6010, L. 75-76.

26. Ob organizatsii Volgogradskogo gosudarstvennogo universiteta. Proekt postanovleniya Soveta Ministrov SSSR ot 17 iyunya 1974 g. [On Establishing Volgograd State University. Draft Resolution of the Council of Ministers of the USSR of June 17, 1974]. GARF [State Archive of the Russian Federation], F. 5446, Op. 108, D. 1091, L. 13; Copies: F. 9606, Op. 1, D. 6010, L. 77.

27. $\mathrm{Ob}$ organizatsii Volgogradskogo gosudarstvennogo universiteta. Vypiska iz protokola zasedaniya Prezidiuma Soveta Ministrov SSSR ot 19 iyunya 1974 g. № 25 [On Establishing Volgograd State University. Extract from the Protocol of the Meeting of the Presidium of the Council of Ministers of the USSR of June 19, 1974 no. 25]. GARF [State Archive of the Russian Federation], F. A-259, Op. 46, D. 4699, L. 21.

28. Ob organizatsii Volgogradskogo universiteta. Pismo ministra prosveshcheniya SSSR v Sovet Ministrov SSSR ot 26 fevralya 1974 g. [On Establishing Volgograd University. Letter of the USSR Minister of Education to the Council of Ministers of the USSR of February 26, 1974]. GARF [State Archive of the Russian Federation], F. 5446, Op. 108, D. 1091, L. 7.

29. Ob organizatsii v g. Volgograde Gosudarstvennogo universiteta. Postanovlenie Soveta Ministrov SSSR ot 21.06.1974 g. № 510 [On Establishing the State University in Volgograd. Decree of the Council of Ministers of the USSR Dated June 21, 1974 no. 510]. GARF [State Archive of the Russian Federation], F. 5446, Op. 1, D. 877, L. 129.

$30 . \mathrm{Ob}$ organizatsii $\mathrm{v}$ g. Volgograde Gosudarstvennogo universiteta. Postanovlenie Soveta Ministrov RSFSR ot 21 oktyabrya $1974 \mathrm{~g}$. № 561 [On Establishing the State University in Volgograd. Decree of the Council of Ministers of the RSFSR of October 21, 1974 no. 561]. GARF [State Archive of the Russian Federation], F. A-259, Op. 1, D. 3161, L. 35; Copies: Op. 46, D. 4699, L. 12.

31 . Ob organizatsii rektorskoy gruppy Volgogradskogo universiteta. Pismo ministra finansov RSFSR i ministra vysshego i srednego spetsialnogo obrazovaniya RSFSR ot 16.05.1979 g. [On Organizing the Rector Group of Volgograd University. Letter of the Minister of Finance of the RSFSR and the Minister of Higher and Secondary Special Education of the RSFSR of May 16, 1979]. GARF [State Archive of the Russian Federation], F. A-259, Op. 46, D. 4699, L. 7.

32. Ob organizatsii rektorskoy gruppy Volgogradskogo universiteta. Pismo predsedatelya ispolkoma Volgogradskogo oblastnogo soveta narodnykh deputatov v Sovet Ministrov RSFSR ot 29.04.1979 № 06-16m/348 [On Organizing the Rector 
Group of Volgograd University. Letter from the Chairman of the Executive Committee of the Volgograd Regional Council of People's Deputies to the Council of Ministers of the RSFSR of April 29, 1979 no. 0616M/348]. GARF [State Archive of the Russian Federation], F. A-259, Op. 46, D. 4699, L. 9.

33. Ob organizatsii universiteta $\mathrm{v}$ g. Volgograde. Spravka zav. otdelom vysshego, srednego i professionalno-tekhnicheskogo obrazovaniya ot 19 iyunya 1974 g. [On Establishing a University in Volgograd. Certificate Issued by the Head of the Department of Higher, Secondary and Vocational Education of June 19, 1974]. GARF [State Archive of the Russian Federation], F. A.-259, Op. 46, D. 4699, L. 22-23.

34. Poruchenie V. Kochemasova ot 17 sentyabrya 1974 g. [Order of V. Kochemasov of September 17, 1974]. GARF [State Archive of the Russian Federation], F. A-259, Op. 46, D. 4699, L. 17.

35. Poruchenie N. Tikhonova ot 28 yanvarya $1974 \mathrm{~g}$. [Order of N. Tikhonov of January 28, 1974]. GARF [State Archive of the Russian Federation], F. 5446, Op. 108, D. 1091, L. 4.

36. Postanovlenie TsK KPSS ot 21 avgusta $1973 \mathrm{~g}$. «Ob organizatsii Gosudarstvennogo universiteta $\mathrm{V}$ g. Volgograde». Protokol № 92 zasedaniya byuro Volgogradskogo obkoma KPSS ot 24 sentyabrya 1973 g. [Resolution of the CPSU Central Committee of August 21, 1973 "On Establishing the State University in Volgograd." Protocol no. 92 of the Meeting of the Bureau of the Volgograd Regional Committee of the CPSU of September 24, 1973]. TSDNIVO [Center of Recent History Documentation of Volgograd Region], F. 113, Op. 89, D. 23, L. $58-59$.

37. Rasporyazhenie V. Kochemasova ot 8 maya 1979 g. [Order of V. Kochemasov of May 8, 1979]. GARF [State Archive of the Russian Federation], F. A-259, Op. 46, D. 4699, L. 8.

38. Rasporyazhenie V. Kochemasova ot 16 marta $1983 \mathrm{~g}$. [Order of V. Kochemasov of March 16, 1983]. GARF [State Archive of the Russian Federation], F. A-259, Op. 46, D. 4699, L. 2.

39. Rasporyazhenie K. Mazurova ot 1 marta 1974 g. [Order of K. Mazurov of March 1, 1974]. GARF [State Archive of the Russian Federation], F. 5446, Op. 108, D. 1091, L. 8.

40. Rasporyazhenie M.S. Solomentseva ot 11 noyabrya 1973 g. [Order of M.S. Solomentsev of November 11, 1973]. GARF [State Archive of the Russian Federation], F. A-259, Op. 46, D. 4699, L. 32.

41. Sidorov S.G. Volgogradskiy gosudarstvennyy universitet. Lyudi. Sobytiya. Fakty. 1980-1999 [Volgograd State University. People. Events. Facts. 1980-1999]. Volgograd, Izd-vo VolGU, 2000. 260 p.
42. Sidorov S.G. Volgogradskomu gosudarstvennomu universitetu - 25 let. 1980 2005 [Volgograd State University is 25 Years Old, 1980-2005]. Volgograd, Izd-vo VolGU, 2005. 399 p.

43. Sidorov S.G. K istorii Volgogradskogo gosudarstvennogo universiteta. 1980-1995: stat. sprav. [To the History of Volgograd State University. 1980-1995. Statistical Handbook]. Volgograd, Izd-vo VolGU, 1996. $136 \mathrm{p}$.

44. Soglasie Soveta Ministrov RSFSR ot 18.05.1979 g. ob organizatsii rektorskoy gruppy Volgogradskogo universiteta [Consent of the Council of Ministers of the RSFSR of May 18, 1979 on the Organization of the Rector Group of the Volgograd University]. GARF [State Archive of the Russian Federation], F. A-259, Op. 46, D. 4699, L. 6.

45. Spravka (ne pozdnee 1 marta $1974 \mathrm{~g}$. [Certificate (No Later than March 1, 1974)]. GARF [State Archive of the Russian Federation], F. 5446, Op. 108, D. 1091, L. 17.

46. Spravka zav. otdelom vysshego. srednego i professionalno-tekhnicheskogo obrazovaniya ot 24 marta 1986 g. [Certificate of the Head of the Department of Higher, Secondary and Vocational Education of March 24, 1986]. GARF [State Archive of the Russian Federation], F. A-259, Op. 46, D. 4699, L. 1.

47. Spravka zav. otdelom vysshego. srednego i professionalno-tekhnicheskogo obrazovaniya ot 15 oktyabrya $1974 \mathrm{~g}$. [Certificate of the Head of the Department of Higher, Secondary and Vocational Education of October 15, 1974]. GARF [State Archive of the Russian Federation], F. A-259, Op. 46, D. 4699, L. 14.

48. Spravka zav. otdelom vysshego. srednego i professionalno-tekhnicheskogo obrazovaniya ot 17 oktyabrya $1974 \mathrm{~g}$. [Certificate of the Head of the Department of Higher, Secondary and Vocational Education of October 17, 1974]. GARF [State Archive of the Russian Federation], F. A-259, Op. 46, D. 4699, L. 13.

49. Spravka-informatsiya zav. otdelom vysshego, srednego i professionalno-tekhnicheskogo obrazovaniya ot 23 marta 1979 g. o khode vypolneniya Minvuzom RSFSR postanovleniya Soveta Ministrov RSFSR № 561 «Ob organizatsii v g. Volgograde gosudarstvennogo universiteta» [Certificate of the Head of the Department of Higher, Secondary and Vocational Education of March 23, 1979 on the Implementation of the Statement of the Council of Ministers of the RSFSR no. 561 "On Establishing a State University in Volgograd" by the Ministry of Higher Education of the RSFSR]. GARF [State Archive of the Russian Federation], F. A-259, Op. 46, D. 4699, L. 10-11. 


\section{УНИВЕРСИТЕТЫ ХХ ВЕКА: ИСТОРИЯ И ПОЛИТИКА}

\section{Information About the Authors}

Sergey G. Sidorov, Doctor of Sciences (History), Professor, Department of Russian and World History, Archaeology, Volgograd State University, Prosp. Universitetsky, 100, 400062 Volgograd, Russian Federation, histrus@volsu.ru, https://orcid.org/0000-0002-1366-5787

Vasily V. Tarakanov, Doctor of Sciences (Economics), Professor, Rector (2015-2020), Volgograd State University, Prosp. Universitetsky, 100, 400062 Volgograd, Russian Federation; Research Advisor, "Institute of Economic and Social Research" Foundation, Prosp. Lenina, 98, 400078 Volgograd, Russian Federation, v.tarakanov@volsu.ru, vtarakanov13@mail.ru, https://orcid.org/0000-0001-6971-0172

\section{Информация об авторах}

Сергей Григорьевич Сидоров, доктор исторических наук, профессор кафедры отечественной и всеобщей истории, археологии, Волгоградский государственный университет, просп. Университетский, 100, 400062 г. Волгоград, Российская Федерация, histrus@volsu.ru, https://orcid.org/0000-0002-1366-5787

Василий Валерьевич Тараканов, доктор экономических наук, профессор, ректор (2015-2020 гг.), Волгоградский государственный университет, просп. Университетский, 100, 400062 г. Волгоград, Российская Федерация; научный руководитель, Фонд «Институт экономических и социальных исследований», просп. Ленина, 98, 400078 г. Волгоград, Российская Федерация, v.tarakanov@volsu.ru, vtarakanov13@mail.ru, https://orcid.org/0000-0001-6971-0172 